\title{
Effects of dietary dihydropyridine on laying performance and lipid metabolism of broiler breeder hens
}

\author{
Z.Y. Niu, Y.N. Min, H.Y. Wang, J. Zhang, W.C. Li, L. Li \& F.Z. Liu ${ }^{\#}$ \\ College of Animal Science and Technology, Northwest A\&F University, Yangling, Shaanxi, 712100, P.R. China
}

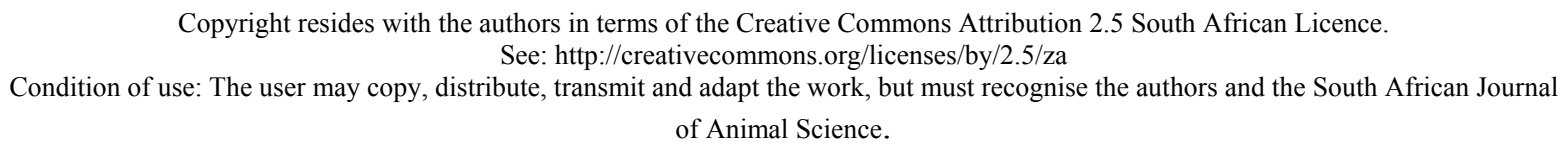

Copyright resides with the authors in terms of the Creative Commons Attribution 2.5 South African Licence.

See: http://creativecommons.org/licenses/by/2.5/za

Condition of use: The user may copy, distribute, transmit and adapt the work, but must recognise the authors and the South African Journal

of Animal Science.

\begin{abstract}
The experiment was conducted to investigate the effects of dihydropyridine supplementation on the laying performance and lipid metabolism of broiler breeder hens. A total of 720 forty-five week old broiler breeder hens were randomly divided into four experimental groups, each group consisting of six replicates of 30 birds. For 10 weeks the birds were fed a maize-soybean meal diet containing 0, 100, 200, $300 \mathrm{mg}$ dihydropyridine $/ \mathrm{kg}$, in the respective treatment groups. The daily egg weight and daily feed intake were not affected by dihydropyridine supplementation, but the laying rate and feed efficiency were significantly increased. The percentage of abdominal fat and percentage of liver fat were significantly decreased by dietary dihydropyridine. A level of $100 \mathrm{mg}$ dihydropyridine/kg had no effect on the hormone-sensitive triglyceride lipase (HSL) activity in the liver or abdominal fat, though higher levels of dietary dihydropyridine $(200 \mathrm{mg} / \mathrm{kg}$ or $300 \mathrm{mg} / \mathrm{kg}$ ) increased HSL activity in the liver and abdominal fat. The concentration of cyclic adenosine monophosphate (cAMP) and superoxide dismutase activity were significantly increased by dihydropyridine, but the malondialdehyde content decreased. The apolipoprotein B concentration was increased at levels of 100 and $200 \mathrm{mg}$ dihydropyridine $/ \mathrm{kg}$, but the $300 \mathrm{mg}$ level had no effect on apolipoprotein B, compared with the control group. The triiodothyronine concentration was significantly increased by dietary dihydropyridine. It is concluded that supplementing dihydropyridine in the diet has a beneficial effect on the laying performance and regulates the fat metabolism of broiler breeder hens. The results suggest that the supplementation of $200 \mathrm{mg}$ dihydropyridine $/ \mathrm{kg}$ diet is the optimal dose for broiler breeder hens.
\end{abstract}

Keywords: Abdominal fat, fatty liver syndrome, lipogenesis, lipolysis

" Corresponding author:1fz@nwsuaf.edu.cn

\section{Introduction}

The modern commercial broiler is the product of intensive selection over many generations, for rapid growth and enhanced muscle mass. Selection for these economically important traits has been accompanied by an increase in voluntary feed intake, resulting in excessive fat, which adversely affects the reproductive performance, and induces fatty liver syndrome (FLS). Fatty liver syndrome is characterized by excessive deposition of fat in the liver due to failure in the lipid metabolism (Butler, 1976; Aydin, 2005; Yousefi et al., 2005). The common symptoms are low-level mortality, sudden drops in egg production and fat content in livers ranging from $40 \%$ to $70 \%$ of the dry liver weight. From a pathological point of view, liver haemorrhaging causes death, it enlarges the liver that has a light brown to yellow colour and is very friable, and a large amount of fat accumulates in the liver, abdominal cavity and around the viscera (Fowler, 1996; Riddell, 1997). Death is usually caused by a fatal internal haemorrhage originating in a portion of the liver. Many studies on FLS in laying hens have been conducted, but there is still no effective solution to overcome the problem.

Dihydropyridine is a new multifunctional antioxidant in food (Kourimska et al., 1993; Smagin, 1998; Tirzitis \& Kirule, 1999; Panek et al., 2000; Tirzitis \& Hyronen, 2001). It has been demonstrated that 
dihydropyridine showed antioxidant and immunological activities in ducks (Bakutis \& Bukis, 1984) and chickens (Val-Dman et al., 1990). Dihydropyridine improved the health of cows, improved the quality of milk and increased cow fertility (Sutkevicius et al., 1984). It also reduced body weight loss in slaughter cattle during transportation to the meat-packing plant (Spruzh \& Igaune, 1991). Dihydropyridine also regulated lipid metabolism in humans (Zhang et al., 2002). Studies indicated that dihydropyridine could improve the laying performance of hens and decrease their hepatic and abdominal fat content (Zou et al., 2007). However, there is no report on the regulation of lipid metabolism by dihydropyridine in broiler breeders. The objective of this study was to evaluate the effects of dietary dihydropyridine supplementation on the laying performance and lipid metabolism of broiler breeder hens.

\section{Materials and Methods}

This experiment was conducted according to the protocol approved by the Northwest A\&F University Animal Care and Use Committee, China. A total of 720 healthy, 45-week old broiler breeder hens were randomly allocated to four groups with six replicates of 30 birds per group. The hens were fed a basal diet consisting of maize-soybean meal (Table 1) in which the respective experimental treatments, 0, 100, 200 and $300 \mathrm{mg}$ dihydropyridine $/ \mathrm{kg}$, were included. The dihydropyridine was provided by Sunpu Biochem. Tech. Co., Ltd, Beijing, China. The hens were housed in battery cages with two per cage, and had free access to feed and water. The experiment lasted 10 weeks. Throughout the experiment the photo-period was set at $17 \mathrm{~h}$ light and $7 \mathrm{~h}$ dark. Feed intake, number of eggs and egg weight were recorded daily.

At the end of the experiment, two birds from each replicate were slaughtered humanely after a $12 \mathrm{~h}$ fast but with free access to water. Abdominal fat pad and liver weights were measured.

Blood samples were collected via vena cava puncture. The serum was harvested by centrifugation at $1000 \mathrm{~g}$ for $10 \mathrm{~min}$ and then stored at $-30^{\circ} \mathrm{C}$ pending analysis. Liver samples were homogenized and dried to a constant weight at $105^{\circ} \mathrm{C}$. Fat from the dried sample $(2 \mathrm{~g})$ was extracted with a chloroform : ether mixture $(5: 1)$ in a Soxhlet apparatus for $8 \mathrm{~h}$, and the extracted sample was dried at $105^{\circ} \mathrm{C}$ to a constant weight. The hepatic fat percentage was calculated as: fat weight/dry liver weight $\times 100 \%$. The liver tissue was homogenized in a $0.9 \%$ sodium chloride solution to make a $10 \%$ hepatic mixture, which was then centrifuged at $2000 \mathrm{~g}$ for $10-15 \mathrm{~min}$. The supernatant was collected for laboratory analyses. The superoxide dismutase (SOD) activity was determined with colorimetry by using the assay kit provided by the Nanjing Jiancheng Bioengineering Institute. Apolipoprotein A (ApoA), apolipoprotein B (ApoB) and malondialdehyde (MDA) concentrations were determined on an UV-2,000 spectrophotometer (UNICO Instruments Co., Ltd., Shanghai, China), using analytical kits obtained from the Ningbo City Bio-chemical Reagent Factory and the Nanjing Jiancheng Bioengineering Institute, China.

Table 1 Ingredient and nutrient levels of the basal diet

\begin{tabular}{lclc}
\hline Ingredients & $\begin{array}{c}\text { Composition } \\
(\mathrm{g} / \mathrm{kg}, \text { air-dry basis })\end{array}$ & Nutrient $^{1}$ & Concentration \\
\hline Maize & 658 & AME $(\mathrm{MJ} / \mathrm{kg})$ & 12.5 \\
Soybean meal & 181.6 & Crude protein $(\mathrm{g} / \mathrm{kg})$ & 153 \\
Rapeseed meal & 43 & Calcium $(\mathrm{g} / \mathrm{kg})$ & 33 \\
Wheat bran & 20 & Non-phytate P $(\mathrm{g} / \mathrm{kg})$ & 4.0 \\
Calcium hydrogen phosphate & 6.3 & Lysine $(\mathrm{g} / \mathrm{kg})$ & 8.4 \\
Stone meal & 77.6 & Met $+\mathrm{Cys}(\mathrm{g} / \mathrm{kg})$ & 5.6 \\
Salt & 3.5 & & \\
Premix* & 10.0 & &
\end{tabular}

*Provided per kilogram of diet: $300 \mathrm{mg}$ retinol; $20 \mathrm{mg} \alpha$-tocopherol; $105 \mathrm{mg}$ cholecalciferol; $75.0 \mathrm{mg}$ niacin; $34 \mathrm{mg}$ D-pantothenic acid; $19.6 \mathrm{mg}$ riboflavin; $5000 \mathrm{mg}$ pyridoxine; $3.4 \mathrm{mg}$ thiamine; $3.3 \mathrm{mg}$ menadione; 3.4 $\mathrm{mg}$ folic acid; $0.35 \mathrm{mg}$ biotin; $0.03 \mathrm{mg}$ cobalamine; $180 \mathrm{mg} \mathrm{Mn} ; 150 \mathrm{mg} \mathrm{Zn;} 20 \mathrm{mg}$ Fe; $2.1 \mathrm{mg} \mathrm{Cu} ; 1.3 \mathrm{mg} \mathrm{I} ; 0.3$ mg Se.

${ }^{1}$ Values are calculated. 
Serum triglycerides (TG), cholesterol, high density lipoprotein-cholesterol (HDL-C) and very low density lipoprotein-cholesterol (VLDL-C) concentrations were measured in an ERBA CHEM-5 semiautomatic biochemical analyzer, using analysis kits provided by Ningbo City Bio-chemical Reagent, China. The hormone-sensitive triglyceride lipase (HSL) activity was measured, using the method reported by Shih (1995). The fat was minced and homogenized in 10 volumes of a $\mathrm{pH} 7.0$ medium containing $0.25 \mathrm{M}$ sucrose, $1 \mathrm{mM}$ EDTA, $4 \mu \mathrm{g}$ leupeptin/mL, $1 \mu \mathrm{g}$ pepstatin $\mathrm{A} / \mathrm{mL}$ and $1 \mathrm{mM}$ dithiothreitol, and then centrifuged at 105 $000 \mathrm{~g}$ for $45 \mathrm{~min}$ at $4{ }^{\circ} \mathrm{C}$. The superficial fat cake was removed and the clear supernatant decanted and used for the assay of HSL activity, based on the standard assay procedure of Nilsson-Ehle \& Schotz (1976). The assay substrate was prepared immediately before use to give a final concentration of each reagent in the 200 $\mu \mathrm{L}$ assay volume as follows: $100 \mathrm{mmol} / \mathrm{L}$ Tris $\mathrm{HCl}, \mathrm{pH} 7.0 ; 5 \mathrm{~g} / \mathrm{L}$ of BSA (fatty acid-free, fraction $\mathrm{V}$ ), and $4.58 \mathrm{mmol}$ triolein/L as substrate. One HSL activity unit is defined as the concentration of enzyme that hydrolyzes $1 \mu \mathrm{mol}$ of olive oil in one minute at $37{ }^{\circ} \mathrm{C}$. Concentrations of triiodothyronine (T3), thyroxine (T4) and insulin in serum were measured, using a RIA kit (Beijing North Immunological Institute, China) and a gamma-counter (Packard 8500, USA).

All the data was analyzed statistically, using the general linear model procedure (SAS, 1989) and the significant differences between the groups were determined with the Duncan multiple range test.

\section{Results}

Compared with the control group, supplementing dihydropyridine improved the laying rate and feed efficiency significantly $(P<0.05)$ (Table 2). Supplementation of 100,200 or $300 \mathrm{mg}$ dihydropyridine $/ \mathrm{kg}$ diet increased laying rate by $8.5 \%, 12.4 \%, 12.7 \%(P<0.05)$, and improved feed efficiency by $7.0 \%, 9.0 \%$, and $8.7 \%(P<0.05)$, respectively. There were no significant differences in the laying rate and feed/egg weight between the treatment containing 100, 200 and $300 \mathrm{mg}$ dihydropyridine $/ \mathrm{kg} \operatorname{diet}(P>0.05)$.

Table 2 The effect of dihydropyridine on laying performance $(n=6)$

\begin{tabular}{|c|c|c|c|c|c|}
\hline \multirow{2}{*}{ Item } & \multicolumn{4}{|c|}{ Dihydropyridine (mg/kg) } & \multirow{2}{*}{ SEM } \\
\hline & 0 & 100 & 200 & 300 & \\
\hline Laying rate $(\%)$ & $60.2^{\mathrm{a}}$ & $65.3^{\mathrm{b}}$ & $67.6^{\mathrm{b}}$ & $67.8^{\mathrm{b}}$ & 1.30 \\
\hline Daily egg weight (g) & 47.6 & 50.5 & 51.1 & 51.9 & 1.15 \\
\hline Daily feed intake (g) & 136.1 & 134.4 & 131.3 & 135.4 & 3.65 \\
\hline Feed/egg weight & $2.86^{\mathrm{a}}$ & $2.66^{\mathrm{b}}$ & $2.57^{\mathrm{b}}$ & $2.61^{\mathrm{b}}$ & 0.12 \\
\hline Liver fat ( $\%$ of dry weight) & $38.5^{\mathrm{a}}$ & $28.1^{\mathrm{b}}$ & $23.3^{\mathrm{b}}$ & $23.0^{\mathrm{b}}$ & 2.60 \\
\hline Abdominal fat $(\% \mathrm{BW})$ & $5.91^{\mathrm{a}}$ & $4.82^{\mathrm{ab}}$ & $4.12^{\mathrm{b}}$ & $3.63^{\mathrm{b}}$ & 1.22 \\
\hline
\end{tabular}

${ }^{\mathrm{a}, \mathrm{b}}$ Within rows, means with different superscripts are significantly different $(P<0.05)$.

Dietary dihydropyridine decreased the liver fat percentage significantly $(P<0.05$, Table 2$)$, but differences between the different doses of dihydropyridine were not significant $(P>0.05)$. The abdominal fat percentage did not differ between the control group and the $100 \mathrm{mg}$ dihydropyridine $/ \mathrm{kg}$ treatment (Table 2), but the 200 and $300 \mathrm{mg} / \mathrm{kg}$ of dihydropyridine supplementation treatments decreased the abdominal fat percentage $(P<0.05)$ compared with the control group. Furthermore, the higher levels of dietary dihydropyridine supplementation $(200$ and $300 \mathrm{mg} / \mathrm{kg}$ ) increased HSL activity $(P<0.05)$ (Table 3$)$.

Dietary dihydropyridine supplementation increased the content of cyclic adenosine monophosphate (cAMP) and SOD activity $(P<0.05$, Table 3$)$, and decreased the MDA content $(P<0.05)$. Levels of 100 and $200 \mathrm{mg} / \mathrm{kg}$ dihydropyridine increased ApoB concentration $(P<0.05$, Table 4$)$, but $300 \mathrm{mg} / \mathrm{kg}$ dihydropyridine supplementation resulted in no difference in ApoB concentration compared with the control group. The T3 concentration was significantly increased by dietary dihydropyridine $(P<0.05)$. However, there were no differences in liver ApoA, serum cholesterol, TG, HDL-C, VLDL-C, T4 and insulin concentrations between dietary treatments. 
Table 3 Effect of dihydropyridine on the activity of the hormone-sensitive triglyceride lipase (HSL) and superoxide dismutase (SOD), and contents of cyclic adenosine monophosphate (cAMP) and malondialdenhyde ( MDA) $(n=6)$

\begin{tabular}{|c|c|c|c|c|c|}
\hline \multirow{2}{*}{ Item } & \multicolumn{4}{|c|}{ Dihydropyridine (mg/kg) } & \multirow{2}{*}{ SEN } \\
\hline & 0 & 100 & 200 & 300 & \\
\hline HSL activity in liver (IU/mg protein) & $38.14^{\mathrm{a}}$ & $41.85^{\mathrm{a}}$ & $44.12^{\mathrm{b}}$ & $43.26^{\mathrm{b}}$ & 0.69 \\
\hline $\begin{array}{l}\text { HSL activity in abdominal fat (IU/mg } \\
\text { protein) }\end{array}$ & $22.2^{\mathrm{a}}$ & $30.6^{\mathrm{ab}}$ & $32.3^{\mathrm{b}}$ & $33.7^{\mathrm{b}}$ & 0.71 \\
\hline cAMP in adenohypophysis (pm/g) & $235.2^{\mathrm{a}}$ & $282.5^{\mathrm{b}}$ & $281.2^{\mathrm{b}}$ & $279.2^{\mathrm{b}}$ & 12.25 \\
\hline SOD (U/mg protein in liver) & $20.0^{\mathrm{a}}$ & $31.7^{\mathrm{b}}$ & $38.1^{\mathrm{b}}$ & $29.9^{\mathrm{b}}$ & 2.51 \\
\hline MDA in mitochondria $(\mathrm{nmol} / \mathrm{L})$ & $1.58^{\mathrm{a}}$ & $1.21^{\mathrm{b}}$ & $1.06^{\mathrm{b}}$ & $1.12^{\mathrm{b}}$ & 0.23 \\
\hline
\end{tabular}

Table 4 Effect of dihydropyridine on apolipoprotein concentration in the liver, and the concentration of all kinds of serum biochemical indications $(n=6)$

\begin{tabular}{|c|c|c|c|c|c|}
\hline \multirow{2}{*}{ Item } & \multicolumn{4}{|c|}{ Dihydropyridine (mg/kg) } & \multirow{2}{*}{ SEM } \\
\hline & 0 & 100 & 200 & 300 & \\
\hline \multicolumn{6}{|l|}{ Liver (mg/100 mg protein) } \\
\hline ApoB & $29.15^{\mathrm{a}}$ & $38.62^{\mathrm{b}}$ & $41.75^{\mathrm{b}}$ & $31.23^{\mathrm{a}}$ & 3.02 \\
\hline ApoA & 19.13 & 18.25 & 18.05 & 20.28 & 1.25 \\
\hline \multicolumn{6}{|l|}{ Serum } \\
\hline Cholesterol (mg/dL) & 119.6 & 116.2 & 119.2 & 121.4 & 22.65 \\
\hline $\mathrm{TG}(\mathrm{mmol} / \mathrm{L})$ & 10.22 & 9.58 & 9.15 & 9.67 & 2.62 \\
\hline VLDL-C (mg/dL) & 1.38 & 1.21 & 1.05 & 1.17 & 0.71 \\
\hline HDL-C (mg/dL) & 125.3 & 132.2 & 140.8 & 129.8 & 19.25 \\
\hline $\mathrm{T} 3(\mathrm{ng} / \mathrm{mL})$ & $1.97^{\mathrm{a}}$ & $2.29^{\mathrm{b}}$ & $2.35^{\mathrm{b}}$ & $2.32^{\mathrm{b}}$ & 0.16 \\
\hline $\mathrm{T} 4$ (ng/mL) & 22.2 & 23.2 & 22.9 & 23.1 & 2.62 \\
\hline Insulin $(\mathrm{ng} / \mathrm{mL})$ & 0.29 & 0.33 & 0.35 & 0.34 & 0.03 \\
\hline
\end{tabular}

\footnotetext{
${ }^{1}$ ApoA - apolipoprotein A; ApoB - apolipoprotein B; TG - triglycerides; VLDL-C - very low density lipoproteincholesterol; HDL-C - high density lipoprotein-cholesterol; T3 - triiodothyronine; T4 - thyroxine.

${ }^{\mathrm{a}, \mathrm{b}}$ Within rows, means with different superscripts are significantly different $(P<0.05)$.
}

\section{Discussion}

The results of this study suggested that dietary dihydropyridine could significantly improve the laying performance of broiler breeder hens, similar to the results in egg-type laying hens, reported by Chen et al. (1993) and Zou et al. (1998; 2007). This study showed that dihydropyridine supplementation significantly reduced the abdominal fat percentage of hens at the late laying stage. Borchni et al. (1991) and Zhang et al. (2002) reported that dihydropyridine decreased the serum lipid concentration through restraining synthesis and absorption of triglyceride and cholesterol. In the present study the dihydropyridine significantly increased HSL activity in abdominal fat. HSL is the key enzyme in adipocyte lipolysis (Diaz et al., 1999; Lien \& Jan, 1999) which can hydrolyze triglyceride to glycerol and fatty acids to meet body requirements. HSL activity is affected by cAMP directly and this study indicated that dihydropyridine improved cAMP level in the adenohypophysis of broiler breeder hens. The cAMP acts as a secondary messenger to activate protein kinase which activates HSL by phosphorylation to make it functional in lipid hydrolysis. 
The present study demonstrated that dihydropyridine significantly increased SOD activity in the liver in broiler breeder hens, and significantly decreased the MDA content of the liver. This observation is similar to the results of Sniedze et al. (1977) who showed that dihydropyridine had an antioxidant function in animals and restrained the oxidation of lipid compounds. SOD protects important organs from attacks by free radicals and maintains their normal physiological function by disposing of excessive free radicals. Paradis et al. (1997) reported that dihydropyridine combined with terminal oxidase cytochrome P450 which form a complex that significantly restrains the activity of NADPH-cytochrome reductase, and thus restrained NADPH production.

Results of this study also showed that dihydropyridine significantly improved the level of ApoB in the liver. ApoB 100 is the most important component of VLDL which is synthesized by the liver and functions in transporting triglycerides out of the liver. ApoB 100 is the most important component of VLDL which is synthesized by the liver. Using immune electron microscopy, Yin et al. (2000) showed that fat was joined to the ApoB chain to form VLDL which then transports endogenetic fat to extrahepatic tissues. Lien \& Jan (1999) pointed out that increased synthesis of ApoB could reduce hepatic fat accumulation and accelerate the transport of fat out of the liver.

Dihydropyridine could regulate incretion in the body (Zou et al., 1999). The present results demonstrate that dihydropyridine increased the T3 level in serum, which agrees with observations by $\mathrm{Wu}$ et al. (1999) in pigs. T3 promotes fat mobilization and enzyme hydrolyzation. Valcavi et al. (1997) and Tashi et al. (1998) found that there was a positive correlation between thyroxine and leptin levels and that thyroxine stimulated the secretion of leptin. Leptin is a protein secreted by the adipocytes which maintains the relative stability of body fat by regulating energy metabolism. Dihydropyridine affected the secretion of T3 and insulin, affected the activity of SOD and HSL, and affected the hepatic and abdominal fat percentages, which showed that dihydropyridine had effects on the synthesis, transportation and deposition of fat in the liver.

\section{Conclusion}

The present research indicated that dietary dihydropyridine could improve the laying performance of broiler breeder hens and decrease their hepatic and abdominal fat percentage by affecting the fat metabolism. The results suggested that a level of $200 \mathrm{mg}$ dihydropyridine $/ \mathrm{kg}$ diet is the optimal dose for broiler breeder hens.

\section{Acknowledgements}

Financial support provided by the Agricultural Research Programme of Shanxi Province in China (Project 2009ZKC10-12) is gratefully acknowledged.

\section{References}

Aydin, R., 2005. Type of fatty acids, lipoprotein secretion from liver and fatty liver syndrome in laying hens. Int. J. Poult. Sci. 4, 917-919.

Bakutis, B. \& Yu Bukis., 1984. Antioxidants in feeding of broiler ducks. J. Ptitsevodstvo. 10, 21-22.

Borchni, N.O., Bond, M.G., Sowers, J.R., Canossa-Terris, M., Buckalew, V., Gibbons, M.E. \& Worthy, A.J., 1991. The multicenter isradipine/diuretic atherosclerosis study: A study of the antiatherogenic properties of isradipine in hypertensive patients. MIDAS Research Group. J. Cardiovasc. Pharm. 18 (Suppl. 3), S15-19.

Butler, E.J., 1976. Fatty liver diseases in the domestic fowl. Avian Path. 5, 1-14.

Chen, J.F., Xiu, Y.J. \& Liu, W.H., 1993. Study on application of feed additive dihydropyridine. Feed Res. 5, 2-5.

Diaz, G.J., Squire, E.J. \& Julian, R.J., 1999. The use of selected plasma enzyme activities for the diagnosis of fatty liver hemorrhagic syndrome in laying hens. Avian Dis. 43, 768-773.

Fowler, N.G., 1996. Nutritional disorders. In: Poultry Diseases. $4^{\text {th }}$ ed. Eds Jordan, F.T.W. \& Pattison, M., W.B. Saunders, London, England. pp. 306-331.

Gordon, D.A., Jamil, H., Sharp, D. \& Mullaney, D., 1994. Secretion of apoliprotein B containing lipoproteins from HeLA cells is dependent on expression of the microsomal triglyceride transfer protein and is regulated by lipid availability. Proc. Natl. Acad. Sci. 91, 7628-7632. 
Kourimska, L., Pokorny, J. \& Tirzitis, G., 1993. The antioxidant activity of 2,6-dimethyl-3,5diethoxycarbonyl-1,4-dihydropyridine in edible oils. Nahrung 37, 91-93.

Lien, T.F. \& Jan, D.F., 1999. The effect on the lipid metabolism of Tsaiya ducks when high levels of choline or methionine are added to the ducks' diet. Asian-Aust. J. Anim. Sci. 12, 1090-1095.

Mac Lachlan, L., Nimpf, J. \& Schneide, R.W.J., 1994. Avian riboflavin binding protein binds to lipoprotein receptors in association with vitellogenin. J. Biol. Chem. 39, 24127-24132.

Nilsson-Ehle \& Schotz, T., 1976. Metabolism of lipids in domestic fowl. J. Biol. Chem. 247, 1234-1241.

Panek, J., Reblova, Z., Kocirkova, L., Trojakova, L., Piskacova, J., Pokorny, J., Duburs, G. \& Tirzitis, G., 2000. Antioxidant activity of dihydropridine derivatives. Czech J. Food Sci. 18, 144-145.

Paradis, V., Kollinger, M., Fabre, M., Holstege, A., Poynard, T. \& Bedossa, P., 1997. In situ detection of lipid peroxidation in chronic liver diseases. Hepatol. 26, 135-142.

Riddell, C., 1997. Developmental, metabolic, and other noninfectious disorders. In: Diseases of Poultry, $10^{\text {th }}$ ed. Eds Calnek, B.W., Barnes, H.J., Beard, C.W., McDougald, L.R. \& Saif, Y.M., Iowa State University Press, Ames, I.A., USA. pp. 913-950.

SAS, 1989. SAS User's guide, Version 6 ( $4^{\text {th }}$ ed.), Volume 2. SAS Institute Cary, N.C., USA.

Shih, M., Taberner, F. \& Peter, V., 1995. Selective activation of brown adipocyte hormone-sensitive lipase and cAMP production in the mouse by $\beta 3$-adrenoceptor agonists. Biochem. Pharmacol. 50, 601-608.

Smagin, A.M., 1998. Antioxidative activity of diludin in foods. Khranenie-i-Pererabotka-Sel'khozsyr'ya. 6, $25-26$.

Sniedze, T.N., Shtokman, A.P., Kiseleva, V.N., Kagen, T.I. \& Gilev, A.P., 1977. Interaction of 2,6-dimethyl,5-dicarbethoxy-1,4-dihydropyridine with enzymes of the NADP.H2-specific electron transport chain of rat liver microsomes. Bull. Exp. Biol. Med. 83, 671-673.

Spruzh, Ya \& Igaune, V.V., 1991. Use of diludin to reduce the body weight loss in young fattening cattle during transport to the meat-packing plant. Trudy-Latviiskoi-Sel'-skokhoz yaistvennoi-Akademii. 270, 60-68.

Sutkevicius, J., Cepulis, J., Burziene, V., Marazas, V., Sililioniene, J. \& Vaitkus, J., 1984. Influence of the antioxidant diludin on productivity, health and reproduction of cows. Lietuvos-VeterinarijosAkademijos-Mokslo-Darbai. 16, 73-82.

Tashi, Y., Naolo, M. \& H. Matsuhiko, H., 1998. Serum leptin concentrations in patients with thyroid disorders. Clin. Endocrinol. 48, 299-302.

Tirzitis, G. \& Kirule, J., 1999. Antioxidant activity of synergism of 2,6-dimethyl-3,5-dialkoxycarbonyl-1,4dihydropyridine (diludin) with BHT and BHA. Czech J. Food Sci. 17, 133-135.

Tirzitis, G., Tirzitis, D. \& Hyvonen, Z., 2001. Antioxidant activity of 2,6-dimethyl-3,5-dialkoxycarbonyl1,4-dihydropyridines in metal-ion catalysed lipid peroxidation. Czech J. Food Sci. 19, 81-84.

Valcavi, R.M., Zini, R., Peino, R., Casanueva, F.F. \& Dieguez, C., 1997. Influence of thyroid status on serum immunoreactive leptins. J. Clin. Endocrinol. Metab. 82, 1632-1634.

Valdman, A.R., Strozha, I.K., Remez, I.M., Vasil-eva, S.V., Spruzh, Y.Y., Veksler, K.M., Markov, Y.G., Kalntsiema, V.K., Glagoleva, T.P., Vevere, L.K., Apsite, M.R. \& Ustinenko, A.N., 1990. Antioxidant and immunological activity of fat-soluble vitamins, zinc and diludin in the feeding of chickens [A]. Usvoenie-Organicheskikh-I-Neorganicheskikh-Soedinenii-V-Organizme-Zhivotnykh [C]. 196-218.

Wu, X.J., Li, C.H. \& Hao, Y.J., 1999. Effects of diludin on pig growth and serum level of T3, T4 and corticosteroid. J. Hebei Agric. Uni. 22, 71-74. (in Chinese).

Yin, J.D., Qi, G.H. \& Huo, Q.G., 2000. Advances in modulation of lipid metabolism in poultry. Acta Zoonutrimenta Sinica 12, 1-7.

Yousefi, M., Shivazad, M. \& Sohrabi-Haghdoost, I., 2005. Effects of dietary factors on induction of fatty liver-hemorrhagic syndrome and its diagnosis methods with use of serum and liver parameters in laying hens. Int. J. Poult. Sci. 4, 568-572.

Zhang, S.Q., Deng, F. \& Mei, J.B., 2002. Activity of 1,4-dihydropyridines in blood lowering fat deposition in adult women. J. Fourth Military Med. Univ. 23, 191-195.

Zou, X.T. \& Ma, Y.L., 1999. Effects of dihydropyridine on incretion of laying hens. J. Zhejiang Agric. Univ. 3, 286-290.

Zou, X.T., Xu, Z.R. Zhu, J.L., Fang, X.J. \& Jiang, J.F., 2007. Effects of dietary dihydropyridine supplementation on laying performance and fat metabolism of laying hens. Asian-Aust. J. Anim. Sci. 10, 1606-1611. 